\title{
Serangan Noldeka \\ Terhadap Autentisitas Al-Qur'an
}

\author{
Bisri Musthofa \\ Dosen Fakultas Humaniora dan Budaya Universitas Islam Negeri (UIN) Malang
}

\section{Abstract}

The missionary orientalists continuouslyattack Muslim community through their teachings. After arguing against sirah nabawiyah, they tried to question the authenticity of the Qur'an. They question both the authenticity of the Qur'an interpretation method and the content of the Qur'an. Hermeneutics is one of the methods of interpreting the Qur'an they offer to replace tafsir and ta' wil methods that the Muslim scholars have used before. Using the method, they raise an issue that the Qur'an is only the product of culture. The issue will distort the sacredness of the Qur'an.

Keywords: authenticity, interpretation.

\section{A. Pendahuluan}

Akhir-akhir ini, ada sebagian orang di kalangan umat Islam -yang boleh jadi pemikirannya telah terkontaminasi oleh pemikiran kaum orientalis baratberpendapat bahwa sebaiknya kaum muslimin tidak perlu bersikap apriori dan curiga terhadap hal-hal yang berbau asing (baca: barat). Umat Islam tidak perlu khawatir kalau-kalau pemikirannya tentang ajaran Islam itu terinfiltrasi oleh pemikiran ajaran Kristen, Yahudi, barat modern dan lain sebagainya. Sebab, menurut pandangan mereka, sudah sejak awal mula kelahirannya Islam telah terinfiltrasi oleh Yahudi-Kristen. Buktinya -masih menurut pandangan mereka-dalam Al-Qur'an kita dapat menemukan cerita tentang Maryam, Musa, bani Israel dan sebagainya. Oleh karena itu, wajar saja jika Islam kemudian juga terus menerus menyerap unsur-unsur asing dalam dirinya, seperti penerapan hermeneutika untuk menafsirkan AlQur'an (Republika, 2Mei 2004). Begitulah kira-kira pendapat segelintir orang dari umat Islam -sebagaimana yang selama ini diharapkan dan diidamidamkan oleh kaum orientalis-missionaris- kepada kaum muslimin lainnya. 
Kalau kita cermati dengan seksama pertumbuhan dan perkembangan orientalisme di dunia barat maka kita akan mengetahui bahwa ternyata target utama kaum missionaris dan orientalis Yahudi-Kristen -setelah nereka gagal "mengobok-obok" sejarah kehidupan (sirah) dan sunnah Rasulullah Shallallahu Alaihi wa Sallam- adalah Al-Qur'an (A. Sa'di al-Farinduany, 1988). Lebih jauh lagi dapat kita katakan bahwa kajian kaum orientalis terhadap Al-Qur'an tidak hanya sebatas mempersoalkan otentisitas dan kemurniannya belaka.

Tetapi ada beberapa isu klasik yang selalu diangkat, di antaranya adalah soal pengaruh "Yahudi, Kristen, Zoroaster dan lain sebagainya terhadap Islam dan isi kandungan $\mathrm{Al}$-Qur'an. Itulah teori pinjam dan pengaruh (the theories of borrowing and influence) yang pertama kali digunakan oleh Abraham Geiger, seorang rabbi Yahudi di Jerman, sebagai pendekatan ilmiah terhadap Islam dengan menerbitkan karyanya yang berjudul "What Did Muhammad Borrow from Judaism?" (Syamsudin Arif, 2005)

Sementara itu, Theodor Noldeke, seorang pendeta di Jerman dan juga dedengkot orientalis terkemuka dalam studi historisitas al-Qu'ran dengan karya monumentalnya (Geschicte des Qorans",(A. Hanafi, MA; 1981) memuji usaha Geiger yang sangat membahayakan sendi-sendi ajaran Islam itu—meskipun pada akhirnya pendapat Noldeke ini juga menuai kritikan dari Friedrich Schwally, yang tak lain adalah muridnya sendiri.

\section{B. Siapakah Theodore Noldeke ?}

Untuk dapat mengetahui pemikiran Noldeke, maka sudah selayaknya kita mengetahui latar belakang pendidikan, lingkungan intelektual, dan beberapa karya ilmiah yang membentuknya.

Theodore Noldeke adalah salah seorang tokoh orientalis terkemuka yang dilahirkan pada 2 Maret 1837 di kota Hamburg Jerman. Ia berasal dari keluarga yang sangat memperhatikan pendidikan anak-anaknya. Ayahnya adalah seorang Wakil Kepala Sekolah Menengah dikota Hamburg dan setelah itu diangkat menjadi Pengawas Sekolah Menengah di kota Lingen pada tahun 1849 hingga 1866. (Abdurahman Badawi; 2003) 
Pada tahun 1853, Noldeke mempelajari bahasa Semit, Persia, Turki, dan Sansekerta di Universitas Gottingen di bawah asuhan $\mathrm{H}$. Ewald, seorang pakar bahasa Semit yang tak lain adalah teman ayahnya sendiri. Akhirnya ia berhasil meraih gelar sarjana tingkat pertama pada tahun 1856 -di saat usianya berkisar 20 tahun-dengan risalahnya yang berjudul "Geschicte des Qorans" (Sejarah Al-Qur'an) dan setelah itu mulai mengadakan kunjungan dan penelitian di berbagai kota besar di Eropah Barat, seperti Wina, Leiden, Leipzig, dan Berlin. (Najib al-Aqiqi)

Pertama kali kota yang dikunjungi oleh Noldeke adalah Wina. Di sana ia menetap selama kurang lebih satu tahun (1856-1857) untuk mempelajari dan meneliti manuskrip-manuskrip yang tersimpan di Perpustakaan Wina. Di saat yang bersamaan, Noldeke juga memperdalam bahasa Persia dan Turki dengan membaca-syair-syair sufistik yang ditulis oleh beberapa penyair besar Persi, seperti Sa'di dan Fariduddin al-Ath thaar.

Setelah itu, ia melanjutkan kunjungan dan penelitiannya ke kota Leiden dari musim dingin tahun 1857 hingga musim semi tahun 1858 . Di kota pelajar yang sejuk ini, Noldeke menjumpai manuskrip-manuskrip Arab yang amat banyak dan beberapa orientalis yang sangat masyhur dan handal, seperti Dozy, juynboll, Mattys de Vries, dan Kuenen. Kepada merekalah Noldeke menjalin hubungan persahabatan yang erat dan belajar membaca manuskrip-manuskrip Arab yang sangat bermutu. Pada saat yang bersamaan, Noldeke juga berkenalan dengan tokoh-tokoh orientalis muda. Belanda yang sedang naik daun seperti de Coeje, de Jong, dan Engelmann.

Kemudian pada 26 April 1858, Noldeke pergi ke kota Berlin untuk meneliti koleksi manuskrip-manuskrip Arab dengan dibantu oleh R. Gosche, seorang orientalis Jerman yang pertama kali menyusun indeks tulisan-tulisan Imam al-Ghozali. Di kota Berlin ini Noldeke menetap hingga tanggal 2 September 1860 (Abdurahman Badawi; 2003).

Dari Berlin, Noldeke melanjutkan lawatannya ke Roma Italia dan menetap di sana selama tiga bulan. Uniknya, meskipun sering bepergian ke luar negara Jerman, tetapi ia tidak pernah sekalipun mengunjungi negerinegeri Arab dan Islam, meskipun hampir seluruh kajian ilmiahnya berkisar tentang bahasa, sastra, sejarah, dan geografi Negara-negara Arab dan Islam (Abdurahman Badawi; 2003). 
Sepulangnya dari Italia—tepatnya pada tahun 1861—Noldeke diangkat menjadi asisten dosen di Universitas Gottingen. Selain itu, Ewaldqurunya - juga memberikan kepercayaan kepadanya untuk mengajarkan tafsir dan tata bahasa Arab. Pada saat yang sama, ia juga mengajarkan kajian syair-syair klasik kepada para mahasiswanya dengan menggunakan bahanbahan yang pernah disalinnya dahulu dari beberapa manuskrip di kota Wina, Leiden, Goeta, dan Berlin. Setelah itu, Noldeke pun mulai menulis dan mengumpulkan kajian tersebut dalam sebuah karya yang berjudul "Beitrage Zur Kanntnis der Poesie der Alten Araber".

Kemudian Noldeke melakukan penelitian terhadap tata bahasa Arab, perbandingan tata bahasa, dan bahasa-bahasa semit yang terdapat dalam dua bukunya yang tebal dengan judul Zur Grammatik des Klassichen Arabish (1897) dan Neue Beitrage zur semitischen Sprachkunde (1911).

Pada tahun 1864-1872, Noldeke ditunjuk sebagai Guru Besar bahasabahasa Semit di Universitas Keil. Selanjutnya pada musim semi tahun 1872 ia diangkat menjadi guru besar bahasa-bahasa timur di Universitas Strassburg hingga tahun 1920 dan sekaligus menjadikan kampus tersebut sebagai Pusat kajian timur di Jerman (Najib al-Aqiqqi).

Pada musim bunga tahun 1920: Noldeke pindah ke kota Karlsruhe, kawasan Rein Atas dan menetap di rumah salah seorang anaknya hingga ia meninggal dunia pada tanggal 25 Desember 1930 (Abdurahman Badawi; 2003).

\section{Pandangan Noldeke dan Kaum Orientalis Terhadap Al-Quran}

Tak dapat diragukan lagi bahwasanya kitab suci Al-Qur'an menempati posisi yang sangat strategis bagi kaum muslimin, yaitu sebagai sumber hukum yang paling otentik dan fundamental dalam agama Islam. Al-Qur'an adalah satu-satunya kitab suci yang dijamin keautentikan dan kemurniannya oleh Allah Subhanahu wa Ta'ala, sebagaimana firman-Nya (al-Hijr:9): "Inna nahnu nazzalna al-zikra wa nahnu lahafizhun (Sesungguhnya kami yang menurunkan Al-Qur'an dan kamilah yang akan memelihatanya)".

Demikianlah Allah Ta'ala menjamin keautentikan dan kemurnian Al-Qur'an, jaminan yang diberikan atas dasar Kemahakuasaan dan 
Kemahatahuan serta berkat upaya-upaya yang dilakukan oleh makhlukmakhluk-Nya, terutama sekalimanusia. Dengan jaminan ayat diatas, maka setiap muslim percaya bahwa apa yang dibaca dan didengar dari Al-Qur'an tidak berbeda sedikit pun dengan apa yang pernah dibaca oleh Rasulullah Shallallahu Alaihi wa Sallam dan dengan apa yang didengar serta dibaca oleh para sahabat Nabi Muhammad (M.Qureish Shihab; 1992). Namun demikian harus kita sadari bahwa pada umumnya kaum oreintalis enggan mengakui bahwasannya Nabi Muhammad SAW telah menerima wahyu Al-Qur'an dari Allah SWT. Mereka biasanya bersikap gegabah dalam menafsirkan tanda-tanda wahyu yang turun kepada Nabi Muhammad, ketika beliau menerimanya secara langsung, dan disaksikan oleh para sahabat lainnya, terutama Siti Aisyah. Oleh karena itu, tidaklah mengherankan apabila ada sebagian diantara mereka, kaum orientalis barat, yang menganggap Nabi Muhammad SAW terkena penyakit ayan (epilepsi), atau ada pula yang menyatakan bahwa wahyu $\mathrm{Al}$-Qur'an itu merupakan produk lamunan Nabi Muhammad dan sebagian ada_yang berpendapat bahwa Nabi Muhammad mempunyai suatu gejala penyakit jiwa (A. Sa'di al-Farinduny; 1988).

Lebih jauh lagi mereka, kaum orientalis: juga berpendapat bahwa Al-Qur'an mengandung hal-hal yang bertentanga antara satu ayat dengan ayat lainnya. Bahkan ada pula beberapa ayat yang tidak masuk akal. Ini tentunya menurut pendapat mereka -adalah sesuatu yang amat lumrah, karena Al-Qur'an adalah buatan Nabi Muhammad dan bukan berasal dari Allah Ta'ala (A.Sa'di al-Farinduny; 1988).

Prof. Fazlur Rahman, seorang cendikiawan muslim Amerika asal Pakistan, menyebutkan salah seorang tokoh orientalis berkebangsaan Yahudi, John Wansbrough, misalnya, yang menyatakan dalam karyanya Quranic Studies bahwa:

1) - Sesungguhnya Al-Qur'an adalah sebuah kitab a la tradition Juive, karena tercipta dalam suasana yang penuh dengan perdebatan sectarian Yahudi-Kristen

2) Al-Qur'an adalah perpaduan dari berbagai tradisi. (3) Al-Qur'an adalah sebuah kitab ciptaan setelah kehadiran Muhammad (Fazlur Rahman; 1983). 
Belum lagi pendapat John Burton dalam karyanya yang berjudul The Collection of The-Qur'an yang menjelaskan bahwa keseluruhan teks AlQur'an itu diedit, dicek, dan disebarluaskan oleh Muhammad sendiri (Fazlur Rahman; 1983).

Bahkan Arthur Jeffrey, seorang orientalis asal Australia yang pernah mengajar di American University Kairo dan menjadi guru besar di Columbia University, berupaya mendekonstruksi al-Mushaf al-Utsmani dan ingin membuat Mushaf baru. Dengan menggunakan metode penelitian kritis modern (biblical criticism), Jeffrey ingin mengedit Al-Qur'an secara kritis (a critical edition of the Qur'an) Ia menganalisis sejarah teks Al-Qur'an dari masa Rasulullah hingga tercetaknya teks bacaan Al-Qur'an (seperti yang kita lihat sekarangiri). Akhirnya ia menyimpulkan bahwa sebenarnya ada berbagai mushaf tandingan (rival codices) terhadap mushaf Utsmani (Republika; 1 April 2005).

Lalu bagaimana pandangan Noldeke terhadap Al-Qur'an? Setali tiga uang. Tidak ada bedanya. Selain memuji teori Geiger yang menyatakan bahwasannya Nabi Muhammad banyak meminjam ajaran agama Yahudi, ternyata ia pun pernah menyatakan pendapatnya tentang Al-Qur'anseperti yang dikutip oleh Joesoef Sou'yb dari buku The Historian's History of The World—Sebagai berikut:

"Kita tidak hanya mempunyai tanggapan-tanggapan yang penuh atas keseluruhan watak Muhammad, yang mana ia juga mempunyai karya yang autentik, yaitu Al-Qur'an, yang disampaikannya atas nama Allah. Namun demikian, tokoh yang luar biasa, menarik, dan sekaligus mengerikan itu dalam banyak hal tetap merupakan suatu teka-teki. Ia banyak mengetahui agama Yahudi dan agama Nasrani hanya melalui laporan lisan belaka. Meskipun tetap merupakan suatu pertanyann: apakah Muhammad itu betul tak pandai membaca dan menulis, tetapi pasti bahwa ia tidak pernah membaca Bible ataupun kita-kitab lainnya. Tokoh-tokoh tempat ia mengumpulkan informasi mengenaiagama-agama tua yang moniteistis itu pastilah pihak yang kurangterpelajar. Terlebih khusus guru-guru pembimbingnya dalam bidang agama Kristen.

Kita mungkin akan kurang bergairah karena melihat begitu banyaknya imajinasi, kekurangan logika, kesederhanaan pemikiran yang tidak 
dapat dibantah dan banyak hal lainnya dalam Al-Qur'an itu. Tetapi semuanya itu bukanlah sesuatu yang merugikan bagi pihak yang mendengarkan Muhammad pada masa itu teristimewa sekali pada saat perhatian mereka terfokus pada satu tujuan. Bahkan semuanya itu terpandang baru bagi mereka. Tergetar oleh kengerian dan kegembiraan mendengarkan neraka dan surga, maka kelemahan penalaran orang yang berpikiran sederhana seperti itu tentang kandungan.Al-Qur'an tidaklah kelihatan, terlebih lagi tekanan tentang soal-soal neraka dan surga berpengaruh kuat pada mereka. Apalagi mereka itu hanya mendengarkan kepingan demi kepingan dan dari waktu ke waktu. Ayat-ayat Al-Qur'an yang dikatakan wahyu itu diterima dalam tempo 20 tahun lebih. Oleh karena itu dapat kita katakan bahwa kejenuhan yang kita rasakan (sekarang) tidaklah kentara bagi orang pada masa tersebut" (Joesoef Sou'yb; 1985).

Dari pernyataan Noldeke tersebut di atas maka yang tergambar-di benak kita atau siapa pun yang membacanya adalah bahwa pada masa sebelum Rasulullah Shallallahu Alaihi wa Sallam menerima wahyu di Goa Hira pada tahun 610 M. Ada sebuah Fakultas Teologi dari suatu kampus ternama di kota Makkah. Kemudian Nabi Muhammad adalah salah seorang mahasiswa yang dengan tekun dan penuh semangat mempelajari pelbagai macam agama dari guru-guru besar Yahudi dan Nasrani sekian tahun lamanya sebagaimana yang dahulu pernah dilakukan Noldeke sendiri ketika ia mengkaji dan mempelajari agama islam. Oleh karena itu kita dapat menyimpulkan bahwasannya Noldeke terlampau mengkhayal dengan pernyataannya yang sangat tendensius seperti tersebut di atas.

\section{Penutup}

Ada sebuah adagium klasik yang menyatakan "Know thy enemies" (Kenalilah musuh-musuhmu!) Seperti itulah kira-kira motto dan senjata kaum orientahs dan missionaris Yahudi-Kristen di balik semua kegiatan dan kegigihan mereka dalam mengkaji Islam dan seluk-beluknya dari berbagai aspek Adalah suatu kecerobohan apabila kita, kaum muslimin, terlampau bersikap berbaik sangka kepada kaum yang tidak akan pernah ridho kepada kita dan senantiasa bersikap memusuhi kita. "Orang-orang 
Yahudi dan Nasrani tidak akan pernah senang hingga kamu mengikuti agama mereka " (al-Baqarah :120).

Selain itu, adalah suatu sikap yang tidak bijaksana apabila kita menelaah mentah-mentah apa yang mereka utarakan dan kemukakan dalam karya-karya mereka. Karena meskipun pengetahuan mereka tentang sejarah pemikiran keislaman dan Al-Qur'an begitu mendalam, namun demikian kajian mereka tetap bersifat fragmentatif. Mereka tidak meghubungkan kajian mereka tentang Islam yang spesifik dengan prinsip yang umum dan universal.Secara umum kajian mereka tentang hal-hal yang spesifik, seperti tentang sejarah $\mathrm{Al}$-Qur'an, etika dalam Islam, politik dalam Islam dan lain sebagainya tidak dikaitkan dengan makna Islam sebagai suatu agama dan pandangan hidup yang memiliki prinsip dan tradisinya sendiri. Wallahu a'lam.

\section{Daftar Pustaka}

Badawi, Abdurrahman, Ensiklopedi Tokoh Orientalis, 2003, pent: Amroeni Drajat, Yogyakarta : LkiS

Sou'yb, Joesoef, Orientalisme dan Islam, 1985, Jakarta-Bulan Bintang Rahman, Fazlur, Tema Pokok Al-Qur'an, 1983, Bandung-Penerbit Pustaka Shihab, M. Qureish, Membumikan Al-Qur'an, Bandung-Mizan, 1992 Al-Aqiqi, Najib, al-Mustasyriquun, jilid II, Kairo-Daarul Ma'arif, t.t Hanafi, MA, A, Orientalisme Ditinjau Menurut Kaca Mata Agama, Jakarta Pustaka al-Husna, 1981

Arif, Dr. Syamsuddin, Al-Qur'an,Orientalisme, dan Luxenberg, dalam Jurnal Kajian Islam Al-Insan, Depok :Vol. I, No. I, Januari 2005

Armas, Adnin, Orientalisme dan Teori Pengaruh Terhadap Islam, dalam harian Republika, Kamis 6 Mei 2004.

Armas, Adnin, Selamat Datang Profesor Azami, dalam harian Republilka Jum'at 1 April 2005. 